\title{
Antiepileptic activity and subtype-selective action of flupirtine at $\mathrm{GABA}_{\mathrm{A}}$ receptors
}

\author{
Mirnes Bajrić, Felicia Klinger, Ulla Schandl, Helmut Kubista, Stefan Boehm \\ From 18th Scientific Symposium of the Austrian Pharmacological Society (APHAR). Joint meeting with the \\ Croatian, Serbian and Slovenian Pharmacological Societies. \\ Graz, Austria. 20-21 September 2012
}

\section{Background}

Flupirtine is used as analgesic drug with muscle-relaxant properties. In addition, it has been suggested to possess antiepileptic properties. Recently, flupirtine has been revealed to simultaneously act at $\mathrm{K}_{\mathrm{V}} 7$ channels and $\mathrm{GABA}_{\mathrm{A}}$ receptors. Here, antiepileptic activity and underlying mechanisms of action of flupirtine were investigated.

\section{Methods}

We used the patch clamp technique and primary cultures of hippocampal neurons or transfected tsA cells to investigate effects of flupirtine.

\section{Results}

In hippocampal neurons, flupirtine reduced seizure-like activity with no effect at 1 to $3 \mu \mathrm{M}$, and maximal effects at 10 to $30 \mu \mathrm{M}$; it enhanced currents through $\mathrm{K}_{\mathrm{V}} 7$ channels with $\mathrm{EC}_{50}$ values at $6 \mu \mathrm{M}$. Flupirtine $(30 \mu \mathrm{M})$ modulated GABA-induced currents in hippocampal neurons by reducing $\mathrm{EC}_{50}$ values for GABA threefold and maximal current amplitudes by $15 \%$. Hence, flupirtine acted as an uncompetitive antagonist. Flupirtine did not alter rise time, decay time, or amplitudes of miniature inhibitory postsynaptic currents (mIPSCs), but enhanced the bicuculline-sensitive tonic current. When phasic GABAergic inhibition was blocked by penicillin $\mathrm{G}$ (5 mM), flupirtine enhanced maximal amplitudes of GABA-evoked currents by $43 \%$, but hardly affected $\mathrm{EC}_{50}$ values. As these results suggested that flupirtine was able to differentiate between different $\mathrm{GABA}_{\mathrm{A}}$ receptor subtypes, its effects on recombinant $\mathrm{GABA}_{\mathrm{A}}$ receptors were

\footnotetext{
* Correspondence: stefan.boehm@meduniwien.ac.at Department of Neurophysiology and Neuropharmacology, Center for Physiology and Pharmacology, Medical University of Vienna, 1090 Vienna,
} Austria

(c) 2012 Bajrić et al; licensee BioMed Central Ltd. This is an Open Access article distributed under the terms of the Creative Commons Attribution License (http://creativecommons.org/licenses/by/2.0), which permits unrestricted use, distribution, and reproduction in any medium, provided the original work is properly cited. investigated in tsA cells. With $\alpha 1 \beta 2 \gamma 2$ receptors, flupirtine reduced $\mathrm{EC}_{50}$ values for GABA threefold and maximal current amplitudes by $25 \%$; with $\alpha 1 \beta 2$ receptors, it reduced $\mathrm{EC}_{50}$ values for $\mathrm{GABA}$ twofold, but reduced maximal current amplitudes by $35 \%$.

\section{Conclusions}

These results indicate that flupirtine (i) exerts antiepileptic activity, (ii) modulates tonic, but not phasic, GABAergic inhibition and blocks $\mathrm{K}_{\mathrm{V}} 7$ channels in hippocampal neurons, and (iii) affects $\mathrm{GABA}_{\mathrm{A}}$ receptors in a subunit-dependent manner.

\section{Acknowledgements}

This study is supported by the Austrian Science Fund (P23658).

Published: 17 September 2012

doi:10.1186/2050-6511-13-S1-A90

Cite this article as: Bajrić et al:: Antiepileptic activity and subtype-

selective action of flupirtine at $\mathrm{GABA}_{\mathrm{A}}$ receptors. BMC Pharmacology and Toxicology 2012 13(Suppl 1):A90.

Submit your next manuscript to BioMed Central and take full advantage of:

- Convenient online submission

- Thorough peer review

- No space constraints or color figure charges

- Immediate publication on acceptance

- Inclusion in PubMed, CAS, Scopus and Google Scholar

- Research which is freely available for redistribution

Submit your manuscript at

\section{Biomed Central}

